\title{
位相最適化手法を用いた CFRPによる中空スラブの最適補強 OPTIMUM REINFORCEMENT OF VOID SLAB BY CFRP USING TOPOLOGY OPTIMIZATION METHOD
}

\author{
藤 井大地*，小泉 智 彦**，森 村 毅*** \\ Daiji FUJII, Tomohiko KOIZUMI and Tsuyoshi MORIMURA
}

\begin{abstract}
Since the possibility of Tokai or Nankai earthquakes, the reinforcement of the buildings is very important. The method using the CFRP tape is effective for the reinforcement of the floor slab. However, since it is relatively expensive, it is necessary to efficiently affix for the CFRP tape. Therefore, in this paper, the topology optimization method (density approach) is used in order to obtain the optimum layout of the CFRP tape. For this purpose, the FEM program for analyzing the laminate plate is developed, and the density approach with CONLIN optimizer is applied. In this program, the solid element based on the hybrid method is used instead of the conventional plate element. In this study, the void slab is used for the floor structure. The effectiveness of the proposed method is shown by the numerical examples and the comparison with the experiment.
\end{abstract}

Keywords : CFRP, topology optimization, void slab, laminate plate, density approach, hybrid method. 炭素繊維板, 位相最適化, 中空スラブ, 積層板, 密度法, ハイブリッド法

1.はじめに

近年, 東海沖地震や南海沖地震の可能性が高まる中, 古い建物 の耐震補強が急務となってきている。このような背景から, 最近, テープ状の炭素繊維樹脂（CFRP）をコンクリートに接着すること で補強を行う方法が開発された。森村ら 1),2) は，この方法を中空ス ラブに適用するため, CFRP 補強を施した中空スラブ試験体の強度, 振動特性に対する実験的研究を行っている。これらの一連の実験 において, CFRP テープの貼り方は, 工学的判断にもとづいて決め られてきたが，実験を効率的に進めるためには，解析的に CFRP テープの貼り付け位置を特定する方法が望まれる。また，CFRP テープは, 比較的高価な材料であるため, 実際の施工においても, 必要最小限の量で，効率的に耐震補強を行うことが求められる。 そこで, 本研究では, CFRP テープの最適な貼り付け位置を求める 方法として，連続体の位相最適化手法を適用することを提案する。

位相最適化手法は，1988 年に Bendsøe と Kikuchi ${ }^{33}$ にっって提案 された方法であり，設計対象となる領域を均一な要素密度を有す る有限要素で徭い，最適化手法によって，必要な要素密度を高く し，不必要な要素密度を低くすることによって，最適な形状を浮 かび上がらせる方法である。当初は，数学的な整合性を持たせる ために, 要素密度を材料のミクロ構造の穴の大きさで制御する均 質化法が用いられたが, 最近では，要素密度を直接設計変数とす

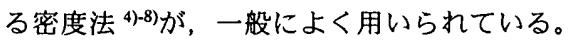

また，板曲げ問題における位相最適化手法は，1992 年に鈴木と 菊池 ${ }^{9}$ が，均質化法を用いた単層板の位相最適化手法を示してい

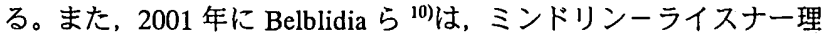
論にもとづく方法で, 1 層または 3 層板の位相最適化を行ってい る。また, 2002 年には, Pedersen ${ }^{111}$ が，マイクロフォンの設計に用 いるためプレストレスの加わる積層板の位相最適化を行っている。 また, 著者の一人である藤井ら ${ }^{12)}$ は, 平面シェル要素を用いてシ エル構造の形状と位相の同時最適化手法を示している。

位相最適化手法を CFRP テープの最適配置を求める問題に適用 するためには，スラブを積層板としてモテル化し，その表層部分 全面に CFRP 材料を仮定し, 体積を絞り込むことによって最適位 相を求めればよい。ただし，この積層板モデルでは，CFRP の有無 によって, 要素の板厚方向の中立軸が変化するため, 板曲げ理論 にもとづく要素の適用は煩雑となる。したがって，本研究では， ソリッド要素を用いた積層板解析プログラムを新たに開発する。 しかしながら, ソリッド要素として, 通常の 8 節点アイソパラメ トリック要素を用いると, 要素内で応力が一定となるため, 板の 曲げモーメント応力を近似するために，板厚方向に多くの分割数 を必要とする。したがって，ここでは，変位も応力もどちらも線 形関数に仮定するハイブリッド法（応力仮定法 ${ }^{13}$ ) ) による要素を 用いる。本要素の採用により, 解析自由度を增やすことなく, 通 常の板曲げ要素と同じ分割数で, ほぼ同等の精度を得ることがで きる。また, 位相最適化手法としては, 密度法を用い, 最適化問 題の解法としては，計算効率のよい CONLIN 法 ${ }^{14), 15), 8)}$ を用いる。

以下, 本論文第 2 章では, ソリッド要素による積層板の解析法 について述べる。第 3 章では, CFRP テープの最適配置を求めるた
* 近畿大学工学部 助教授・博士(工学)

** 近畿大学工学部 大学院生

*** 近畿大学工学部 教授. 博士 (工学)
Assoc. Prof., School of Engineering, Kinki University, Dr. Eng.

Graduate Student, School of Engineering, Kinki University

Prof., School of Engineering, Kinki University, Dr. Eng. 
めの位相最適化問題の定式化と解法について述べる。第 4 章では, CFRP 補強を行う中空スラブ試験体を对象として, 位相最適化手法 により最適な CFRP テープの配置を求め, これと工学的判断にも とづく基本的な配置モデルとの比較を行う。また，実験結果を考 察することにより，本提案手法の有効性を検討する。最終第 5 章 では，以上のまとめを述べる。

\section{2. 積層板の解析法}

\section{1 要素方程式の定式化 ${ }^{13)}$}

CFRP 補強を施した積層板を解析する場合，図1に示すように， CFRPで補強されている部分とそうでない部分の中立軸が異なる。 したがって，板曲げ要素を用いると，プログラミングが煩雑にな る。したがって, 本研究では, 積層板を解析するための要素とし て，3 次元ソリッド要素を用いる。しかしながら, 通常の 8 節点 アイソパラメトリック要素では, 要素内で応力が一定であるため, 図 2 に示すように，曲げに対する応力を再現するために，少なく とも板厚方向に 8 分割程度分割することが必要となる。

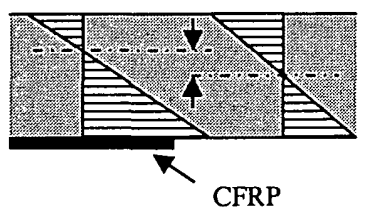

図 1 CFRP 補強による中立 軸のずれ

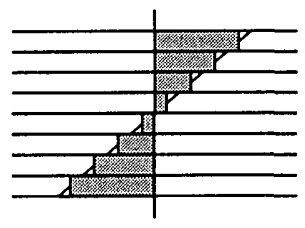

図 2 曲げモーメント応力分布 （要素内一定応力）
そこで, ここでは, 要素内の変位も応力も共に線形に仮定する ハイブリッド要素 ${ }^{13)}$ を用いる。この方法では, 要素内の変位と座 標は通常のアイソパラメ.トリック要素と同様に次式で仮定する (図 3 参照)。

$$
\begin{aligned}
& u(x, y, z)=\mathbf{N}(\xi, \eta, \zeta) \mathbf{u}^{e} \\
& v(x, y, z)=\mathbf{N}(\xi, \eta, \zeta) \mathbf{v}^{e} \\
& \text { (1) } \\
& x=\mathrm{N}(\xi, \eta, \xi) \mathrm{x}^{\mathrm{e}} \\
& w(x, y, z)=\mathbf{N}(\xi, \eta, \zeta) \mathbf{w}^{e} \\
& y=\mathbf{N}(\xi, \eta, \zeta) \mathbf{y}^{e} \\
& z=\mathbf{N}(\xi, \eta, \zeta) \mathbf{z}^{\mathrm{e}}
\end{aligned}
$$

ここに, $u, v, w$ は $x, y, z$ 方向の変位, $\mathrm{N}$ は形状関数, $\mathrm{u}^{e}, \mathbf{v}^{e}, \mathbf{w}^{e}$ と $\mathbf{x}^{e}, \mathbf{y}^{e}, \mathbf{z}^{e}$ は，節点変位と節点座標のベクトルであり，具体的には 次のように表される。

$$
\begin{aligned}
& \mathbf{u}^{e}=\left[\begin{array}{llllllll}
u_{1} & u_{2} & u_{3} & u_{4} & u_{5} & u_{6} & u_{7} & u_{8}
\end{array}\right] \\
& \mathbf{v}^{e}=\left[\begin{array}{llllllll}
v_{1} & v_{2} & v_{3} & v_{4} & v_{5} & v_{6} & v_{7} & v_{8}
\end{array}\right] \\
& \mathbf{w}^{e}=\left[\begin{array}{llllllll}
w_{1} & w_{2} & w_{3} & w_{4} & w_{5} & w_{6} & w_{7} & w_{8}
\end{array}\right] \\
& \mathbf{x}^{e}=\left[\begin{array}{llllllll}
x_{1} & x_{2} & x_{3} & x_{4} & x_{5} & x_{6} & x_{7} & x_{8}
\end{array}\right] \\
& \mathbf{y}^{e}=\left[\begin{array}{llllllll}
y_{1} & y_{2} & y_{3} & y_{4} & y_{5} & y_{6} & y_{7} & y_{8}
\end{array}\right] \\
& \mathbf{z}^{e}=\left[\begin{array}{llllllll}
z_{1} & z_{2} & z_{3} & z_{4} & z_{5} & z_{6} & z_{7} & z_{8}
\end{array}\right]
\end{aligned}
$$

また，応力も次式のように仮定する。

$$
\mathbf{\sigma}=\left\{\begin{array}{c}
\sigma_{x} \\
\sigma_{y} \\
\sigma_{z} \\
\tau_{x y} \\
\tau_{y z} \\
\tau_{z x}
\end{array}\right\}=\left\{\begin{array}{c}
c_{11}+c_{12} y+c_{13} z+c_{14} y z \\
c_{21}+c_{22} z+c_{23} x+c_{24} z x \\
c_{31}+c_{32} x+c_{33} y+c_{34} x y \\
c_{41}+c_{42} z \\
c_{51}+c_{52} x \\
c_{61}+c_{62} y
\end{array}\right\}=\mathbf{N}_{s} \mathbf{c}
$$
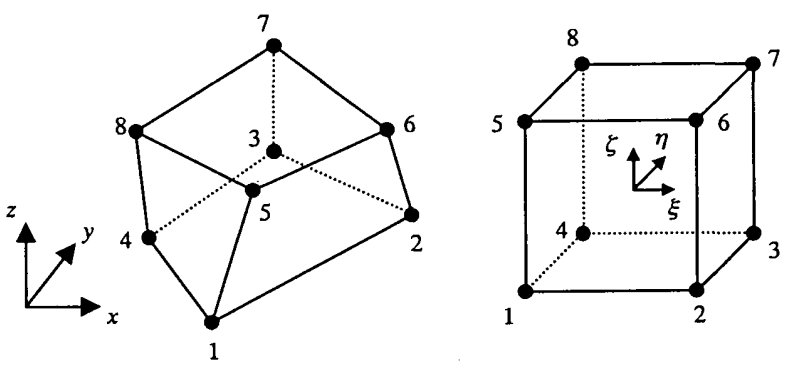

図 3 ８節点アイソパラメトリック要素

ただし， $c_{11} \cdots, c_{62}$ は未定係数を表す。

この場合，(1)式と(5)式から2つの歪みベクトル

(1)式から得られる歪み $\varepsilon=\mathbf{B d}^{e}$

(5)式から得られる昰み $\varepsilon=D^{-1} \boldsymbol{\sigma}=D^{-1} N_{s} c$

が得られる。ただし， $\varepsilon$ は歪みべクトル， $\mathbf{B}$ は歪み一変位マトリ クス，Dは弾性マトリクスである。これら2つの歪みを適合させ るため, 次式の条件を課す。

$$
\iiint_{\Omega^{*}} \delta \mathbf{\sigma}^{T}\left[\mathbf{D}^{-1} \mathbf{N}_{s} \mathbf{c}-\mathbf{B d}^{e}\right] d \Omega=0
$$

ただし， $\Omega^{e}$ は要素の領域を表す。

(8)式の $\sigma に(5)$ 式を代入すると次式が得られる。

$$
\mathbf{c}=\mathbf{M}_{S}^{-1} \mathbf{M}_{B} \mathbf{d}^{e}
$$

ただし，

$$
\mathbf{M}_{s}=\iiint_{\Omega^{*}} \mathbf{N}_{s}^{T} \mathbf{D}^{-1} \mathbf{N}_{s} d \Omega, \quad \mathbf{M}_{B}=\iiint_{\Omega^{*}} \mathbf{N}_{s}^{T} \mathbf{B} d \Omega
$$

また，(7)式より，

$$
\varepsilon=\mathbf{D}^{-1} \mathbf{N}_{s} \mathbf{M}_{s}^{-1} \mathbf{M}_{B} \mathbf{d}^{e}=\overline{\mathbf{B}} \mathbf{d}^{e}
$$

したがって，要素剛性マトリクスは次式より得られる。

$$
\mathbf{k}^{e}=\iiint_{\Omega^{e}} \overline{\mathbf{B}}^{T} \mathbf{D} \overline{\mathbf{B}} d \Omega=\mathbf{M}_{B}{ }^{T} \mathbf{M}_{S}{ }^{-1} \mathbf{M}_{B}
$$

(12)式の剛性マトリクスを用いる解析では, 未知数は通常のアイ ソパラメトリック要素と同じ $\mathbf{d}^{e}$ となる。したがって, 解析自由度 は同じで，しかも，(5)式で示されるように垂直応力が座標に関し て線形で仮定されるため, 図 2 に示されるような応力分布は 1 要 菜で再現できる。

\section{2 中空スラプの解析}

中空スラブは, 直交異方性板にモテル化することによって解析 する。この場合, 3 次元たわみ性マトリクス $\mathbf{D}^{-1}$ は次のように表さ れる。

$$
\mathbf{D}^{-1}=\left[\begin{array}{cccccc}
1 / E_{1} & -v_{12} / E_{1} & -v_{13} / E_{1} & 0 & 0 & 0 \\
& 1 / E_{2} & -v_{23} / E_{2} & 0 & 0 & 0 \\
& & 1 / E_{3} & 0 & 0 & 0 \\
& & & 1 / G_{12} & 0 & 0 \\
& & & & 1 / G_{23} & 0 \\
\text { sym. } & & & & & 1 / G_{31}
\end{array}\right]
$$

鉄筋コンクリート中空スラブにおいては, (13)式の各成分は次の ように計算される 16),17)（図 4 参照）。まず，ヤング係数は，

$$
\begin{aligned}
E_{1}= & {\left[\left\{1-\left(\phi^{\prime} / t\right)^{3}\right\}+6 p_{t}^{x}\left(1-v^{2}\right)\left(E_{s} / E_{c}-1\right)\left(1-2 d_{t}^{x} / t\right)^{2}\right] E_{c} } \\
E_{2}=\left[\left\{1-\left(\phi^{\prime} / t\right)^{3}\right\}+\left\{1-\left(L / l_{p}-1\right) \phi^{\prime} / L\right\}\left(1-v^{2}\right)\left(\phi^{\prime} / t\right)^{3}\right. & \\
& \left.\left.+6 p_{t}^{y}\left(1-v^{2}\right)\left(E_{s} / E_{c}-1\right)\left(1-2 d_{t}^{y} / t\right)^{2}\right\}\right] E_{c} \\
E_{3}= & \left(l_{p}-\phi^{\prime}\right) E / l_{p}
\end{aligned}
$$


ここに， $\phi^{\prime}$ は，円形鋼管断面と断面積の等しい正方形の 1 辺の長 さ $\left(\phi^{\prime}=\sqrt{\pi \phi^{2} / 4}\right), \phi$ は中空鋼管の直径, $t$ はスラブ厚, $p_{t}^{x}, p_{1}^{y}$ は $x, y$ 方向の引張鉄筋比, $d_{t}^{x}, d_{1}^{y}$ は $x, y$ 方向の鉄筋のかぶり厚; $v$ は コンクリートのポアソン比, $E_{s}, E_{c}, E$ は鉄筋, コンクリート, 鉄 筋コンクリートのヤング係数， $l_{p}$ は中空鋼管の中心間距離， $L$ は 正方形スラブの 1 辺の長さを表す。また，せん断弾性係数は，

$$
\begin{aligned}
G_{12} & =\frac{\left(t-\phi^{\prime}\right) G / t \kappa+\left(t l_{p}-\phi^{\prime 2}\right) G / t l_{p} \kappa}{2} \\
G_{23} & =\frac{1}{\left(l_{p}-\phi^{\prime}\right)} \cdot \frac{1}{\phi^{\prime 2} / 12 E I_{x}+\kappa / G\left(l_{p}-\phi^{\prime}\right)} \\
G_{31} & =\frac{G}{\kappa} \cdot \frac{\phi^{\prime}\left(l_{p}-\phi^{\prime}\right)}{l_{p} t}
\end{aligned}
$$

ここに, $G$ はコンクリートのせん断弾性係数, $\kappa$ は形状係数, $I_{x}$ は図 4 に示される領域の断面 2 次モーメントを表す。

(13)式を(10)式に代入し，(12)式の要素剛性マトリクスを計算す ることにより, 中空スラブの有限要素解析を行うことができる。

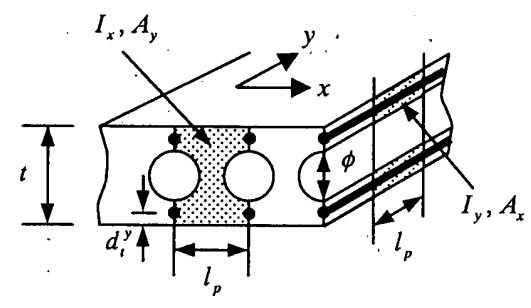

図 4 中空スラプの断面と表記

\section{3. 位相最適化問題の定式化}

\section{1 最適化問題の定式化}

本問題は，図 5 に示すように櫴層板の表面に CFRP 材料の層を 設定し，重量の制約の下に, CFRP 材料の要素密度を最適化するこ とで，CFRPの最適位相を求める問題となる。

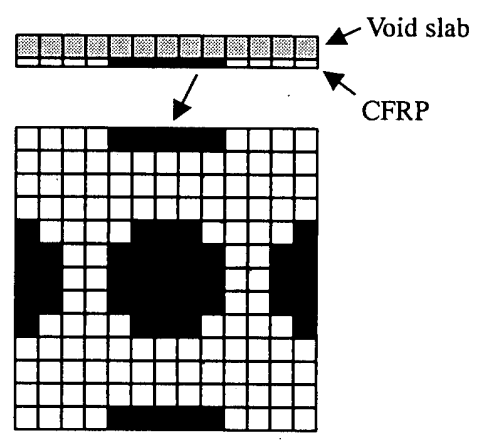

図 5 CFRP テープの最適配置を求める位相最適化問題

したがって, 本問題の設計変数は, CFRP 材料要素の密度, 制約 条件は CFRP 材料の総重量となる。また, 最適化の目的は, CFRP 補強によりスラブの剛性を高めることとし，目的関数をコンプラ イアンス（歪みエネルギーの 2 倍）として，これを最小化する。

以上の最適化問題を定式化すると次のようになる。

$$
\begin{gathered}
\min \quad C(\mathbf{x})=\mathbf{d}^{T} \mathbf{k}(\mathbf{x}) \mathbf{d}=\sum_{i=1}^{n} \mathbf{d}_{i}^{e T} x_{i}^{p} \mathbf{k}_{i}^{e} \mathbf{d}_{i}^{e} \\
\text { subject to } \quad W(\mathbf{x})=\sum_{i=1}^{n} x_{i} v_{i}^{e} \leq \overline{\bar{W}} \\
0 \leq x_{i} \leq 1 \quad(i=1, \cdots, n)
\end{gathered}
$$

ここに，Cはコンプライアンス， $\mathbf{k}$ は全体剛性マトリクス， $\mathbf{d}$ は 節点変位べクトル, $x_{i}$ は 0 以上 1 以下の要素密度を表す設計変数, $n$ は設計変数の総数, $\mathbf{d}_{i}^{e}, \mathbf{k}_{i}^{e}$ は $i$ 番目要素の節点変位べクトルと剛 性マトリクス, $W$ は総重量, $v_{i}^{e}$ は $i$ 番目要素の体積, $\bar{W}$ は重量の 制約值を表す。また， $p$ は，0 と.1の間の中間的な密度を防ぐた めのペナルティ係数である（通常 2〜3で与える）。

\section{2 最適化問題の解法}

ここでは，(16)式の最適化問題を，CONLIN 法によって解く。 CONLIN 法は，目的関数および制約条件を，既知の設計変数の近 傍で, 感度係数が正であれば設計変数で, 感度係数が負であれば 設計変数の逆数でテーラー展開して解く方法である。詳しくは文 献 14),18)等を参照。CONLIN 法を用いる場合も, 目的関数と制約 条件の設計変数に関する感度係数が必要となるが, これらは次式 から計算される。

$$
\frac{\partial C(\mathbf{x})}{\partial x_{i}}=-p x_{i}^{(p-1)}\left(\mathbf{d}_{i}^{e T} \mathbf{k}_{i}^{e} \mathbf{d}_{i}^{e}\right), \quad \frac{\partial W(\mathbf{x})}{\partial x_{i}}=v_{i}^{e}
$$

また，繰り返し計算の各ステップでは，設計変数に変動幅（move limit）の制約を課す必要がある。すなわち,

$$
x_{i}^{(k-1)}-\zeta \leq x_{i}^{(k)} \leq x_{i}^{(k-1)}+\zeta
$$

ここに， $k$ は最適化計算の繰り返しステップ, $\zeta$ はムーブリミッ トを表す（通常 0.1 以下で与える）。

\section{4. 解析例}

\section{1 解析モデル}

ここでは，図 6 に示す中空スラブ試験体を対象として，図7に示 す解析モテルにより解析を行う。解析モデルでは， $\phi=3.2 \mathrm{~cm}$, $t=6 \mathrm{~cm}, p_{t}^{x}=0.00298, p_{t}^{y}=0.00317, d_{t}^{x}=0.9 \mathrm{~cm}, d_{t}^{y}=1.2 \mathrm{~cm}, v=0.167$ $E_{c}=1892 \mathrm{kN} / \mathrm{cm}^{2}, E_{s}=2058 \mathrm{kN} / \mathrm{cm}^{2}, E=1919 \mathrm{kN} / \mathrm{cm}^{2}, l_{p}=5 \mathrm{~cm}$ $L=100 \mathrm{~cm}, \kappa=1.2, I_{x}=84.9 \mathrm{~cm}^{4}, \phi^{\prime}=2.8 \mathrm{~cm}$ としている。なお，解析 モデルでは，中空円形鋼管が $y$ 軸方向に入っているものとしている。 この場合, 中空スラブの材料定数は, (14),(15)式の計算により次の ようになる。

$$
\begin{aligned}
& E_{1}=1862 \mathrm{kN} / \mathrm{cm}^{2}, \quad E_{2}=1911 \mathrm{kN} / \mathrm{cm}^{2}, \quad E_{3}=831 \mathrm{kN} / \mathrm{cm}^{2} \\
& G_{12}=424 \mathrm{kN} / \mathrm{cm}^{2}, \quad G_{23}=292 \mathrm{kN} / \mathrm{cm}^{2}, \quad G_{3 i}=419 \mathrm{kN} / \mathrm{cm}^{2} \\
& v_{12}=v_{23}=v_{13}=0.167
\end{aligned}
$$

一方，CFRP は，等方性とした場合と，異方性とした場合の 2 種 類の解析を行う。ただし，異方性とした場合は, CFRP 材料の要素 を 2 重に重ねることによって解析を行う。

CFRP を等方性とした場合の CFRP の材料定数は，

$$
E=16224 \mathrm{kN} / \mathrm{cm}^{2}, \quad v=0.28
$$

また，CFRPが異方性の場合は，一方が，

$$
\begin{aligned}
& E_{1}=16224 \mathrm{kN} / \mathrm{cm}^{2}, \quad E_{2}=300 \mathrm{kN} / \mathrm{cm}^{2}, \quad E_{3}=300 \mathrm{kN} / \mathrm{cm}^{2} \\
& G_{12}=G_{23}=G_{31}=117 \mathrm{kN} / \mathrm{cm}^{2}, \quad v_{12}=v_{23}=v_{13}=0.28
\end{aligned}
$$

他方が $E_{1}$ と $E_{2}$ の值を入れ替えた值とする。なお，炭素緎維方向と 直交方向のヤング係数およびせん断弾性係数はエポキシ樹脂のも 
のを用いている。

解析は，対称性を利用して $1 / 4$ 領域で行う。境界条件は全辺完全 固定とし, 荷重は $17.87 \mathrm{kN} / \mathrm{m}^{2}$ の鈶直等分布荷重とする。

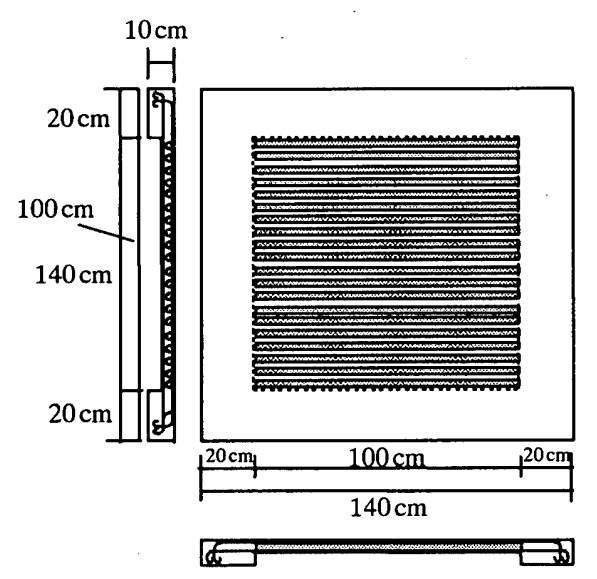

図 6 中空スラブ試験体

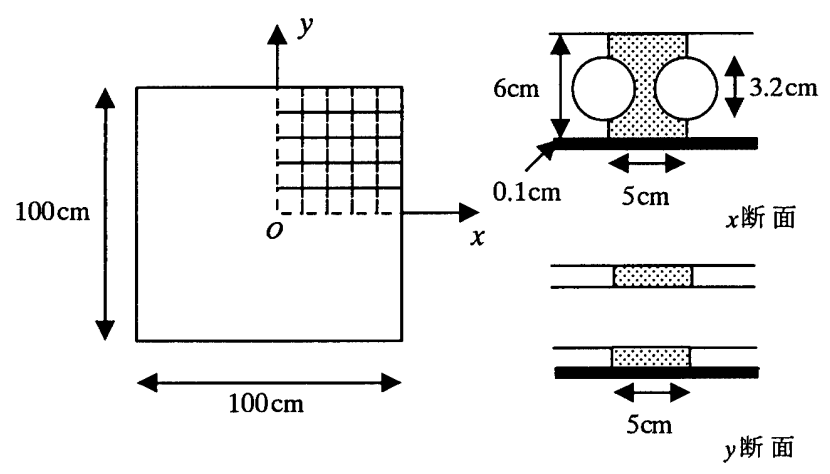

図 7 解析モデル

\section{2 有限要素分割に対する収束性}

まず，本論文に示したソリッド要素の有限要素分割に対する収 束特性を示す。解析モデルは, 4.1 節に示した CFRP 部分を除いた 中空スラブモデルとする。

図 8 は, 板厚方向の分割数を 1 として， $x, y$ 方向の分割数を 5 $\times 5,10 \times 10,15 \times 15,20 \times 20,25 \times 25,30 \times 30$ (1/4 領域) とし た場合の中央たわみの収束性を示したものである。図より，5×5 分割で十分な精度が得られていることがわかる。ただし, 図の繸 軸の值は, 中央たわみを $30 \times 30$ 分割の值で無次元化している。

図 9 は， $x, y$ 方向の分割数を $20 \times 20$ として, 板厚方向の分割数 を $1,2,4,6,8,10$ とした場合の, 中央たわみの収束性を示したもの である。図より，板厚方向 1 分割で, 十分な精度が得られている ことがわかる。ただし, 図の縦軸の值は, 板厚方向 10 分割の值で 無次元化している。

以上の結果を踏まえ, 以下の解析では, 有限要素分割数を $x, y$ 方 向は $20 \times 20$ 分割, 板厚方向は, CFRP が等方性の場合は 2 層, 異 方性の場合は, 同じ 2 層ではあるが CFRP 部分の要素は 2 倍にし て計算する。なお, $x, y$ 方向の分割数を $20 \times 20$ としたのは, 詳細 な位相を求めるためである。

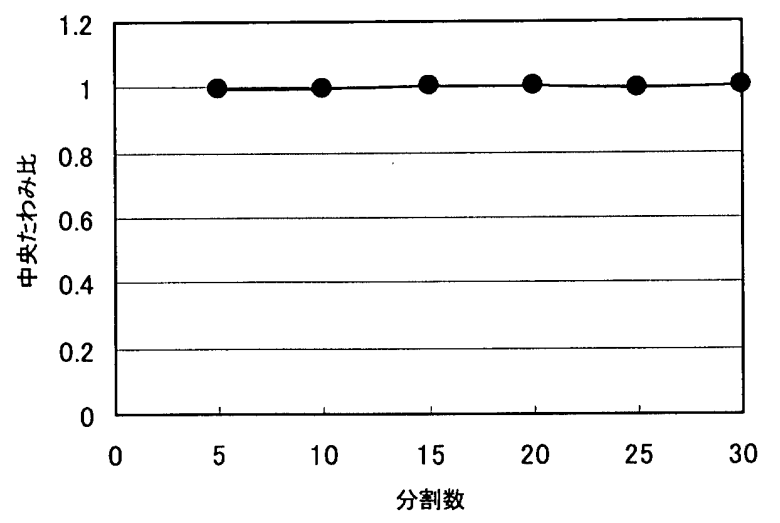

図 $8 x, y$ 方向の分割に対する中央たわみの収束性

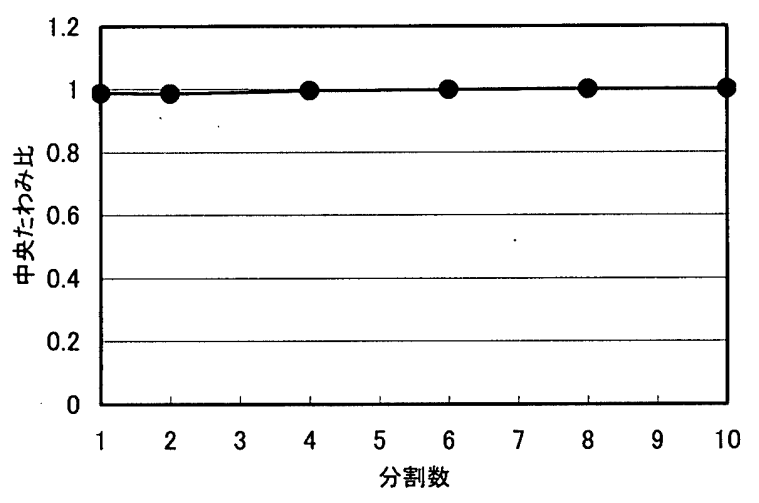

図 9 板厚方向の分割に対する中央たわみの収束性

\section{3 位相最適化の条件と解析結果}

位相最適化計算では，(16)式の目的関数のべき乗係数 $p$ を 2 と し, 重量の制約值 $\widetilde{W}$ は, 実験を考慮して全 CFRP 要素の重量の $32 \%$ （CFRP が異方性の場合は 16\%）に設定する。また，(18)式のムー ブリミット $\zeta$ は 0.1 とし, 最適化計算の繰り返し数は 40 とする。 なお，本解析では，チェッカーボード状の位相分布を回避するフ イルタリング法は用いていない。

図 10 は，最適化計算の繰り返し数に対する(16)式のコンプライ アンス値の収束性を示したものである。ただし, 図の縦軸の值は, 40 ステップのコンプライアンス值で無次元化している。 図より, 30 ステップ程度でほぼ収束していることがわかる。

図 11 は，CFRP を等方性として解析した場合の結果を示す。ま た, 図の右側に, 設計変数の値と色のケールの関倸を示している。 図に示されるように，スラブの応力が高くなる中心部分と各辺の 中央部分が CFRP で補強されていることがわかる。また，スラブ の異方性は，CFRPの分布には反映されていないことがわかる。し たがって，1 方向中空スラブの場合，スラブ部分を等方性として 解析しても問題ないと思われる。

図 12 は，CFRP を異方性として解析した場合の結果を示す。た だし，色のスケールは，図 11 に示されるものと同じである。図よ り，等方性の結果とほぼ同様な位相が得られていることがわかる。 ただし，この場合は，スラブの上下辺に関しては $y$ 方向に, 左右 辺に関しては $x$ 方向に CFRP テープを貼ればよいことがわかる。 また，スラブ中央部は，どちらも密度が 0.5 近くのグレースケー 
ルになっているため,ここは技術者の判断により，等方的に貼る 必要がある。

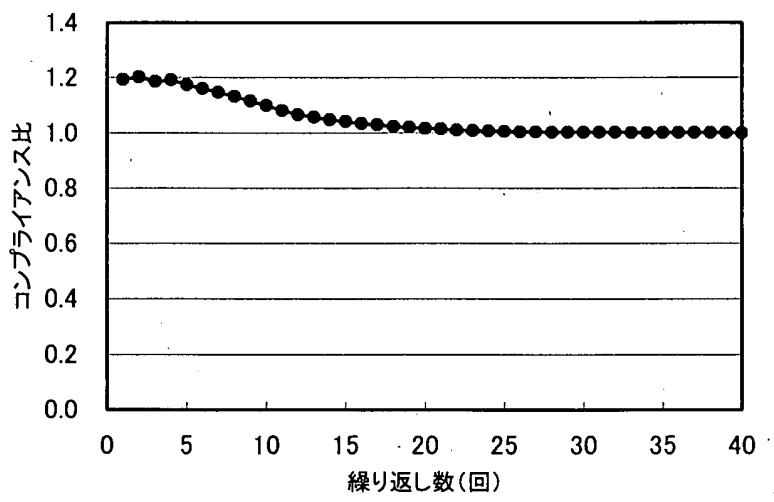

図 10 最適化の反復計算回数に対するコンプライアンスの収束性

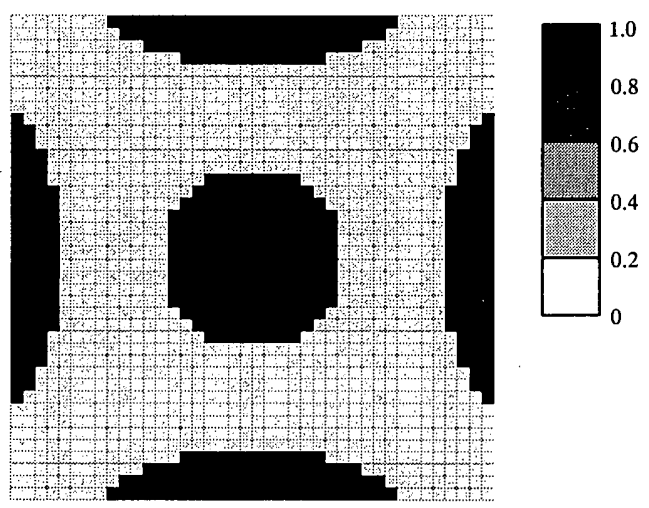

図 11 解析結果（CFRP が等方性の場合）

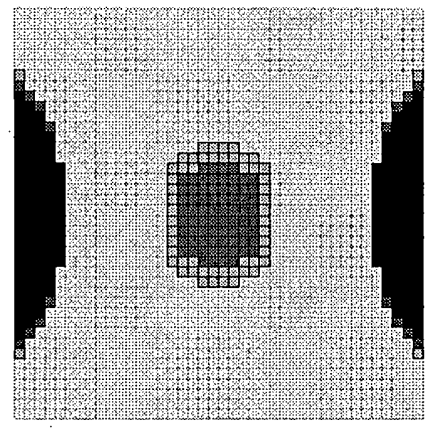

(a) $E_{1}$ が大きい要素

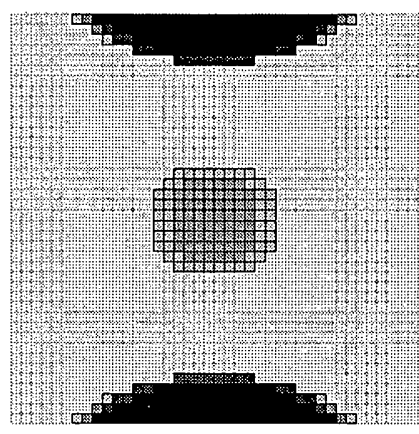

(b) $E_{2}$ が大きい要素
図 12 解析結果（CFRP が異方性の場合）

\section{3 工学的判断に基づく貼り方との比較}

前節の結果を参考にして, 実際の CFRP テープの幅も考慮した 図 13 の解析モデルを作成した（Case4）。また，本モデルの有効性 を検討するため, 図 14 に示す 3 つの比較モテル（Case1〜Case3） を作成した。これらの比較モデルは, Case1は, スラブの弱軸の強 化を，Case2 は，スラブの等方的な強化を目的としており，Case3 は，降伏線上のひび割れを遅らせ，曲げ耐力の増大を目的とした 貼り方である。ただし，以上の 4 つの解析モデルでは, CFRP の面
積が微妙に異なり, Case4 と比較して, Case1 は約 $11 \%$, Case2 は 約 22\%, Case3 は約 4\%CFRP の面積が大きくなっている。

表 1 は，以上の 4 ケースについて，スラブ中央のたわみ值とス ラ.ブに生じる最大応力を比較したものである。表より, 図 13 の最 適解にもとづくモテルの剛性が最も高く，スラブの応力も低減さ れていることがわかる。

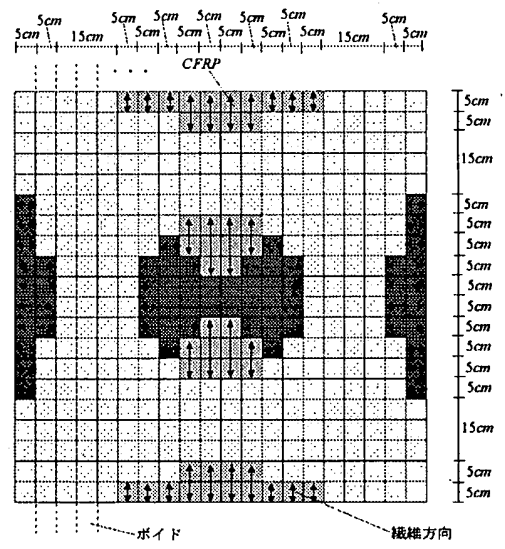

図 13 CFRP テープの貼り付けを考慮した解析モデ（Case4）

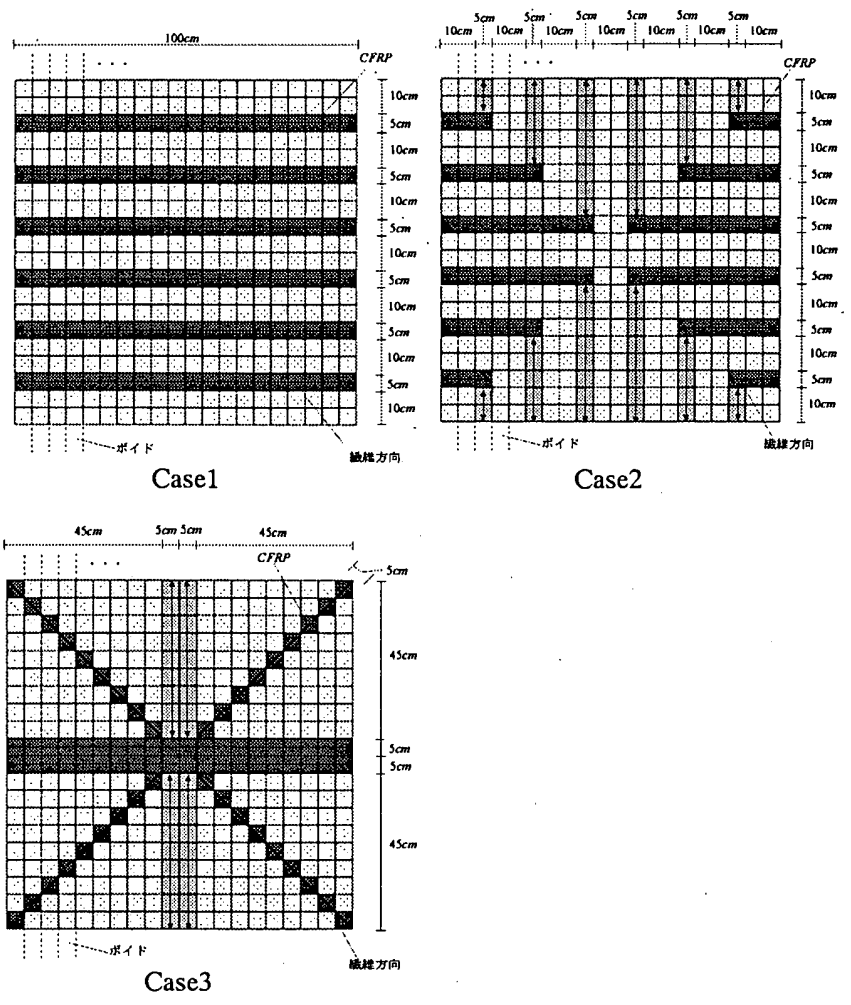

図 14 工学的判断にもとづく比較モデル

表 1 スラブ中央たわみとスラブの最大応力の比較

\begin{tabular}{|c|c|c|c|c|}
\hline & Case1 & Case2 & Case3 & Case4 \\
\hline 中央たわみ & $7.525 \times 10^{-3} \mathrm{~cm}$ & $7.433 \times 10^{-3} \mathrm{~cm}$ & $7.175 \times 10^{-3} \mathrm{~cm}$ & $6.716 \times 10^{-3} \mathrm{~cm}$ \\
\hline$\sigma_{x}^{\max }$ & $1.423 \mathrm{~N} / \mathrm{mm}^{2}$ & $1.397 \mathrm{~N} / \mathrm{mm}^{2}$ & $1.374 \mathrm{~N} / \mathrm{mm}^{2}$ & $0.836 \mathrm{~N} / \mathrm{mm}^{2}$ \\
\hline$\sigma_{y}^{\max }$ & $1.424 \mathrm{~N} / \mathrm{mm}^{2}$ & $1.386 \mathrm{~N} / \mathrm{mm}^{2}$ & $1.356 \mathrm{~N} / \mathrm{mm}^{2}$ & $0.818 \mathrm{~N} / \mathrm{mm}^{2}$ \\
\hline
\end{tabular}




\section{4 実験値の比較}

次に，前節に示したモデルを対象として，試験体を作成し，実 験を行った。実験の詳細に関しては, 文献 19)を参照。

図 15 は各試験体の各段階のひび割れ時の荷重を最大荷重で割 って到達率としたものである。ただし，初期段階は，スラブの上 面か下面のどちらかに最初にひびが入った段階, 第 2 段階は, 最 初に斜めにひびが入った段階, 第 3 段階は, 対角線上にひびが入 つた段階，第 4 段階は，スラブに降伏線が形成された段階, 最終 段階は，破壊に至った段階である。

図 15 から Case4 の初期ひび割れ段階の到達率が約 57\%と他の Case に比べ高率であることがわかる。したがって，実験において も，最適解を参考にした試験体が最も高剛性となっていることが 検証された。なお, Case4 で，第 3 段階の到達率が低いのは, 図 13 からわかるように, 本モデルでは対角線上の CFRP 補強がない ためと考えられる。

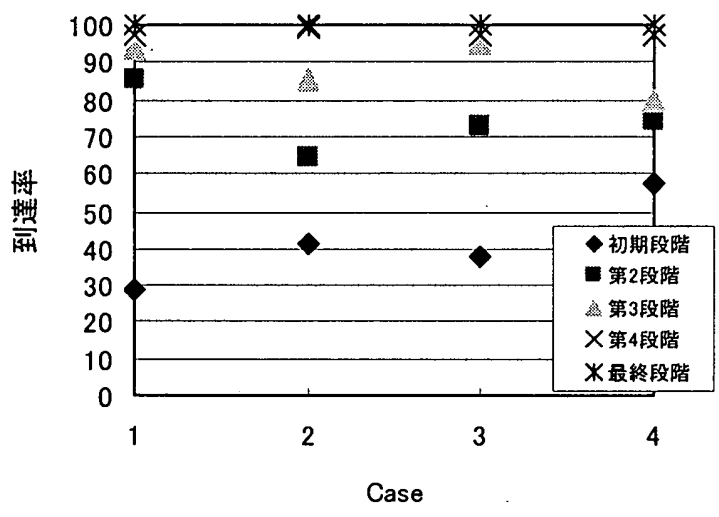

図 15 ひび割れ発生到達率

\section{5.まとめ}

本論文では，CFRPテープによる床スラブの耐震補強を効率よく 行うために，位相最適化手法を用いてCFRPの適切な貼り付け位置 を求める手法を提案した。本手法では，スラブを積層板にモテル化 し，CFRPテープを貼り付ける層を設計領域として，密度法による 位相最適化手法を適用した。

開発したプログラムにより，本手法の有効性を調査した結果，工 学的判断に基づく貼り方に比較して, 最適位相を参考にした貼り方 の方が，スラブの剛性が高いことが検証された。また, 同じモデル で, 試験体を作成し，実験を行ったところ，最適位相を参考にした 貼り方による試験体が，他の試験体に比較して初期のコンクリート のひび割れまでの強度が高いことがわかった。

以上より，本論文で提案した手法は，CFRP テープの効率のよ い貼り方を求める方法として有効であることが確認できた。ただ し，実験の結果，最終強度の比較では，必ずしも最適位相を参考 にした貼り方の試験体が最大とはならなかったため，今後は，弾 塑性解析に拡張し，強度を目的関数にする方法も必要であると考 えられる。これについては, 今後の課題としたい。
謝辞 : 本研究を遂行するにあたり, 近畿大学工学部大学院生の中 川恭一君に協力していただいた。ここに，記して感謝の意を表し ます。

\section{参考文献}

1）森村毅，在永末徳：鉄筋コンクリート梁・スラブの炭索䄉維補強に関 する研究，日本建築学会中国支部研究報告第 24 爷，pp29-32, 2001.3

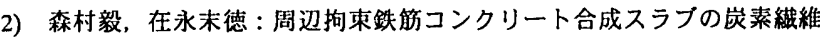
補強に関する研究，日本建築学会中国支部研究報告第 25 卷, pp121-124, 2002.3

3) Bendsøe, M.P. and Kikuchi, N., Generating Optimal Topologies in Structural Design using a Homogenization Method, Computer Methods in Applied Mechanics and Engineering, 71, pp.197-224, 1988

4) Bendsøe, M. P., Optimal shape design as a material distribution problem, Struct. Optimiz., 1, 193-202, 1989

5) Zhou, M. and Rozvany, G.I.N., The COC algorithm, Part ?: Topological, geometrical and generalized shape optimization, Computer Methods in Applied Mechanics and Engineering, 89, 309-336, 1991

6) Yang, R.J. and Chuang, C.H., Optimal topology design using linear programming, Computers \& Structures, 52(2), 265-275, 1994

7）藤井大地，鈴木克幸，大坪英臣：ボクセル有限要素法を用いた權造物 の位相最適化，日本計算工学会論文集，Vol.2，pp.87-94，2000

8）藤井大地，鈴木克幸，大坪英臣：最適化手法 CONLIN を用いた 3 次元 構造物の位相最適化，土木学会応用力学論文集，Vol.4, pp.69-77, 2001.10

9) Suzuki, K. and Kikuchi, N., Generalized Layout Optimization of Three-Dimensional Shell Structures, Geometric Aspects of Industrial Design, SIAM, Philadelphia, pp.62-88, 1992

10) Belblidia, F., Lee, J. E. B., Rechak, S. and Hinton, E., Topology optimization of plat structures using a single- or three-layered artificial material model, Advances in Engineering Software, Vol.32, pp.159-168, 2001

11) Pedersen, N. L., Topology optimization of laminated plates with prestress, Computers \& Structures, Vol.80, pp.559-570, 2002

12）藤井大地，获池昇，均筫化法によるシェル粠造の形状とトポロジーの 同時最適化，日本建築学会大会学術講演梗概集，满造 I，pp.383-384, 1999.9

13）関口美奈子，料池暴，混合的な有限要素剛性マトリックスの導き方に 関する一考察ーClough 1960 年の論文を中心として一, 計算工学荫演会 墖文集, 4(1)，pp.131-134, 1999

14) C. Fleury and V. Braibant : Structural Optimization: A new dual method using mixed variables, International Journal for Numerical Methods in Engineering, Vol.23, pp.409-428, 1986

15）藤井大地，鈴木克幸，大坪英臣，最適化手法 CONLIN を用いた骨組構 造の位相最適化，日本建築学会權造系論文集，No.548，2001.10

16）森村毅，直交異方性鉄筋コンクリートスラブの荷重変形特性に関する 研究, 広島大学博士諭文, pp.170-176, 1989

17) 藤本敬之, 中空スラプについて (第一報), 近幾大学理工学部研究報告, pp.59-60, 1969

18）藤井大地著,「パソコンで解く構造デザイン」, 丸善， 2002.4

19）森村毅，小泉智彦，藤井大地，周辺拘束中空スラブの炭素繀維補強に 関する研究，日本建策学会中国支部研究報告集，第 27 巻，pp.361-364, 2004.3 